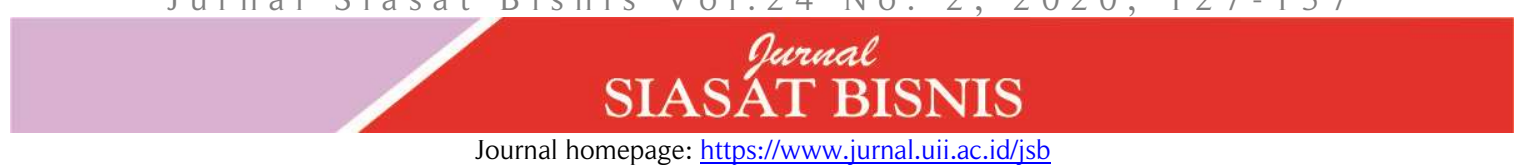

\title{
Building supply chain collaboration on SMEs: The role of ICT and trust
}

\author{
Titik Kusmantini $^{1 *}$, Agung Satmoko², Krisnandini Wahyu Pratiwi ${ }^{3}$, Arum Kurniawati ${ }^{4}$ \\ ${ }^{1,2,3}$ Department of Management, FEB UPN "Veteran" Yogyakarta, Indonesia \\ ${ }^{4}$ Student of Management Department, FEB UPN "Veteran" Yogyakarta, Indonesia \\ "Corresponding author: titik.kusmantini@upnyk.ac.id
}

\begin{abstract}
This study aims to investigate the relationship between information and communication technology (ICT), trust, and supply chain collaboration and their impact on companies' operational performance. Partial Least Square (PLS) was used to test the research models. A survey was conducted to collect data from screenprinting SME, which is one of the leading creative industries, in Yogyakarta. Questionnaires were directly distributed and collected from 48 SMEs. The results show that trust and ICT have a significant and direct effect on supply chain collaboration and operational performance. The indirect effect of ICT and trust on operational performance through supply chain collaboration also prove to be significant. The practical implication of this research is the importance of SMEs understanding of the strategic role of technology in sharing information, because with ICT, companies will be able to build more effective business communication. Besides, it is also important to understand the role of trust as a factor supporting the companies' commitment to building sustainable cooperation and achieving higher operational performance.
\end{abstract}

Keywords: Information and Communication Technology (ICT); Trust; Supply Chain Collaboration; Operational Performance

JEL Classification Code: M15

DOI: $10.20885 /$ jsb.vol24.iss2.art3

\section{Introduction}

Collaboration enables firms to achieve differential performance using the resources and routines among the diverse members of the supply chain (Dyer and Singh, 1999). Fawcett, Watson and Magnan (2012) argue that collaboration can facilitate faster development of new products, enhance their quality, lower production cost and shorten fulfillment time. Only few companies have achieved the high-level collaboration required to yield breakthrough performance (Mentzer and Ladd, 2007). Several researchers such as Barrat (2004), Fawcett et al (2012), and Salam (2017) argue that information and communication technology (ICT) is a substantial investment, and with advanced technology, can create agile supply chain collaboration and achieve the shared goals among parties in the supply chain.

Fawcett, Magnan and William (2004) also emphasize that ICT will facilitate the process of sharing information, and thereby suppress opportunistic behavior and eliminate intra-firm conflicts. However, the topic of supply chain collaboration research in Small and Medium Enterprises (SMEs) settings is rarely studied (Papakinakopoulos, 2010). According to Papakinakopoulos, most of the SMEs collaborate on the downstream end or their relationship with the customers. Only few companies have focused on managing information on the upstream end or their relationship with the suppliers, and thus trigger weak competitiveness. This is in line with Kusmantini and Untoro's (2019) study that reveals the potential of ICT utilization in Indonesia's SMEs to focus on managing information to respond the changing customer requirement and demand. However, Indonesian SMEs have a weakness in managing information with suppliers that leads to supply chain risk. For example, the business failure of furniture companies in Indonesia was triggered by the weak collaboration between companies and suppliers to meet required export documents (Kusmantini, Haryono, Untoro and Setiawan, 2018). 
Efforts to boost SMEs' performance is needed to assess the extent of supply chain collaboration capabilities both upstream and downstream. Referring to previous studies such as Fawcett, Mc Carter, Fawcett, Webb and Mognan (2015), Fawcett et al (2012) and Salam (2017), the structure resistor of collaboration, and the two resistors are interconnectedness to information sharing and trust. Trust enables cooperative behavior and can reduce harmful conflicts and decrease transaction costs. Kwon and Taewon (2004) argue that trust is a critical factor to create long term collaboration and can measurably improve the chance of successful supply chain performance. A lack of trust among supply chain partners often result in inefficient and ineffective collaboration, because the process needs verification, inspection, and certification of their trading partners. The literature often mentions a relationship between trust and information sharing, but there is a lack of empirical testing of such relationship in the supply context.

Special Region of Yogyakarta (DIY) is one of the provinces where various types of Small and Medium Enterprises (SMEs) focusing on creative industries grow and thrive, such as those in the culinary, fashion, craft, and photography subsectors. DIY has the smallest total creative business units of 172,230 units. However, despite having the smallest number of creative business units, it is the largest contributor to GDP for creative economy in 2016 with $16.12 \%$, followed by Bali with $12.57 \%$, West Java with $11.81 \%$, East Java with $9.37 \%$, and North Sumatra with $4.55 \%$ (bekraf.go.id, 2018). In 2016, the largest sub-sector contribution was from the fashion industry (bekraf.go.id, 2018). In the screen-printing sector, efforts to build effective and efficient performance is needed, because the market is both volatile and unpredictable.

The results of the literature review point to the importance of trust as well as ICT to support supply chain collaboration. Collaboration allows faster development of new products, higher quality products, lower product and supply chain costs, shorter cycle times, and improved customer service (Cachon and Fisher, 2000; Frohlich, 2002; Ketchen et al., 2007; Rinehart et al., 2008). High confidence as well as modern and up-to-date ICT will form a strong supply chain collaboration, which in turn can improve the operational performance of SMEs focusing on creative industries. This study aims to identify a mediating role of the supply chain collaboration on the effect of trust and ICT on operational performance (a study on screen-printing SMEs in Yogyakarta).

\section{Literature Review}

\section{Enablers of Performance and Supply Chain Collaboration}

\section{Effect of trust on operational performance}

Trust is often defined as the willingness to take risks (Mayer et al., 1995) and a willingness to rely on an exchange partner in which a person has the confidence. Supply chain management is built on a foundation of trust and commitment (Doney and Cannon, 1997; Lee and Billington, 1992). Ganesan (1994) argue that the long-term orientation in buyer supplier relationship depends on the extent to which the retailer or vendor and channel partners believe in their perception of trust. Kwon and Taewon (2004) state that the successful performance of a company (operational performance) in the supply chain is influenced by highly valued trust and a strong commitment among partners in the supply chain. From theoretical point of view, it can be concluded that in order to improve operational performance, inter-organizational trust must be implemented in each interaction along the supply chain. Therefore, the first hypothesis states:

H1: Trust positively influences the operational performance of screen-printing SMEs in Yogyakarta

\section{Effect of Information and Communication Technology (ICT) on Operational Performance}

In general, the Information Technology (IT) has been widely recognized as an important factor in the supply chain because of its contribution to improving the performance of both individual companies and the overall supply chain (Salam, 2017). IT plays a major role in operational 
effectiveness, which increases the competitive advantage of the supply chain management and further strengthens both customer and supplier relationships (Tripathy, 2016). In addition, the technological resources have a positive effect on the level of support for technical functions in the value chain (Rasheed and Geiger, 2001). Dubey and Ali (2015) found that the technology has a strong impact on the performance of long-term supply chain. Information technology is affecting the development of economy, business, technology and information which lead to increased competitiveness in any type of business. To be able to compete in today's economy, companies are required to ensure that their policy making is always effective and efficient to maintain their viability (Tripathy, Aich, Chakraborty, \& Lee, 2016). Therefore, the second hypothesis states:

$\mathrm{H} 2$ : Information and communication technology (ICT) positively influences the operational performance of Screen-printing SMEs in Yogyakarta

\section{Effect of Trust on The Supply Chain Collaboration}

Collaboration of two or more companies can be successful if it is laid out based on trust (Salam, 2017). Trust is often regarded as the most important motivating factor for supply chain collaboration (Matopoulos et al., 2007; Fedorowicz, 2008; Fynes et al., 2008;). One of the most important qualities to have for each company in the supply chain is a network of trust among organizations (Chopra and Meindl, 2007). Anderson and Narus (1990) define trust as a belief that will provide positive results for the organization. Moorman et al. (1993) outline trust as a belief or positive expectation obtained through exchange with partners in a supply chain system. Trust is the bond that holds a collaborative relationship (Spekman and Carraway 2006). Trust has been proven to improve collaboration, leading to open communication and information sharing (Morgan and Hunt, 1994; Ring and Van de Ven, 1994; Cummings and Bromiley, 1996; Smith and Barclay, 1997). Confidence, the extent to which partners view each other as credible and generous (Doney and Cannon, 1997; Ganesan, 1994; Kumar et al., 1995), is expected to have a positive effect on the level of collaboration in the supply chain relationship. Fawcett et al. (2012) state that collaboration in the supply chain is about building trust. Therefore, the third hypothesis states:

H3: Trust positively and significantly influences the supply chain collaboration of Screen-printing SMEs in Yogyakarta

\section{Effect of ICT on Supply Chain Collaboration}

Information and communication technology (ICT) is one key aspect in the supply chain collaboration. ICT support allows management to make business decisions more quickly and accurately (Munizu, 2015). Levi et al. (2004) define information technology (IT) as tools, either hardware or software, used to determine the existence of information and analyzes such information to make the best decisions for the supply chain. In general, ICT has been widely recognized as an important factor in the supply chain because of its contribution to improving the performance of both individual companies and the overall supply chain. Dubey and Ali (2015) found that the technology has a strong impact on the performance of long-term supply chain. Therefore, the fourth hypothesis states:

H4: Information and communication technology (ICT) positively and significantly influences the supply chain collaboration of Screen-printing SMEs in Yogyakarta

\section{Effect of Supply Chain Collaboration on Operational Performance}

Previous studies (Harrison et al., 2001; Fawcett et al., 2008; Mentzer et al., 2008; Cantor et al., 2010) have shown that the ability to identify and connect the complementary capabilities through collaboration leads to superior performance. Furthermore, the collaboration enables faster development of new products, better product quality, lower product cost, shorter cycle times, and improved customer service (Cachon and Fisher, 2000; Frohlich, 2002; Ketchen et al., 2007; Rinehart 
et al., 2008). Collaboration benefits include increased revenue, reduced costs, and operational flexibility to cope with the high demand uncertainty (Fisher, 1997). To build a successful collaborative relationship, it is important that the partners work together to plan and coordinate the activities, as well as to solve the problem. Therefore, the fifth hypothesis states:

H5: Supply chain collaboration positively influences the operational performance of Screen-printing SMEs in Yogyakarta

\section{The Role of Supply Chain Collaboration as a Mediating Variable}

Some studies suggest that joint efforts have enabled partners to align their operations and processes, which improve relationships by building trust. When companies collaborate, they are more likely to commit to a relationship (Jap and Ganesan, 2000). Joint decision-making incentivizes the suppliers to commit (Subramani and Venkatraman, 2003), while joint efforts are expected to improve overall supply chain performance. Therefore, the sixth hypothesis states:

H6a: Supply chain collaboration mediates the effect of trust on operational performance of screenprinting SMEs in Yogyakarta

Myhr and Spekman (2005) found that collaborative partnership can be achieved through trust or electronically mediated exchange (e.g. information technology). As the electronically mediated exchange helps people at the operational level who need the latest information to carry out their roles effectively, it is likely to have a direct impact on collaboration. The use of ICT enables the creation of optimal information sharing among partners in the supply chain and to support supply chain collaboration which will then improve operational performance. Therefore, the sixth $b$ hypothesis states:

H6b: Supply chain collaboration mediates the effect of ICT on operational performance of screenprinting SMEs in Yogyakarta

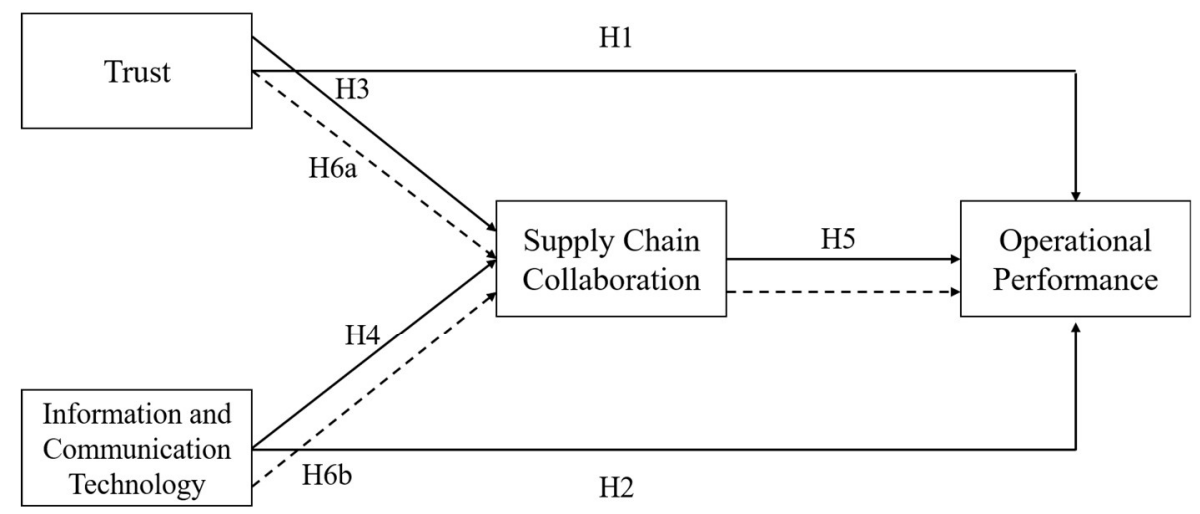

- - - $\rightarrow$ = Mediation Path

Figure 1. The causal relationship among variables in this study

\section{Methods}

This research is a survey study, namely a systematic collection of information from respondents to understand and predict some aspects of the behavior of the population of interest. The population in this study was all screen-printing SMEs in Yogyakarta. The samples were obtained using the NonProbability Sampling method. The method used in this study was convenience sampling, or a sampling technique based on chance, in that anyone who accidentally meets the researchers can be used as a sample if the person is deemed suitable as a data source (Hair et al, 2005). In this study, 
samples taken were 48 screen-printing SMEs in Yogyakarta that have implemented supply chain collaboration.

Validity test was performed to measure whether the questionnaire, as the measuring tool, is accurate. The questionnaire is considered valid if the questions are able to reveal something measured by the questionnaire. The validity testing in this study used the validity which correlates the score of each question item with a total score which is the sum of each score point. If the significance value is $\alpha \leq 0.05$, an item is considered valid (Ghozali, 2011). Reliability test was performed to determine the extent to which the measurement results remain consistent if the measurement is done more than once against the same indicators using the same measuring instrument. According to Ghozali (2011), if the value of Cronbach Alpha is $>0.60$, the question is considered reliable, but if the value is $<0.60$, the question is judged unreliable.

This study used Partial Least Square (PLS) with Smart PLS application version 3.2.8. The PLS, according to Jogiyanto and Abdillah (2009), is a structural equation analysis (SEM) based on variants that can simultaneously perform both measurement model and structural model testing. Measurement model is used to test validity and reliability, while the structural model is tested for causality (hypothesis testing with predictive models). Hair et al (2005) explain that the PLS is an analytical method that is both soft modeling because it does not assume that the data must meet a certain scale measurement, which means that the number of samples can be small (fewer than 100 samples).

\section{Results and Discussion}

The first part of model evaluation is to assess the results of the measurement model (outer model). The measurement model evaluation was done by testing Convergent Validity, Discriminant Validity, and Unidimensionality.

\section{Convergent Validity}

Convergent Validity value is the value of the loading factor on the latent variables with their indicators with the expected value of $>0.7$. Figure 1 shows that the values of all loading factors were $>0.7$. In addition to loading factor values, convergent validity can also be seen from the Average Variance Extracted (AVE). In this study, the AVE value of each construct was higher than 0.5 . Therefore, there is no convergent validity problem in the models tested.



Figure 2. The results of PLS 


\section{Discriminant Validity}

As convergent validity problem is not found, the next step is to test for problems related to the discriminant validity. This value is the value of cross loading factor that is useful to identify whether the construct has adequate discriminant by comparing the value of the loading on the intended constructs, which must be greater than the value of the loading with the other constructs.

Table 1 below shows that the loading of each item against the intended construct was greater than the value of its cross loading, meaning that there is no discriminant validity problem.

Table 1. Cross Loading

\begin{tabular}{|c|c|c|c|c|}
\hline & Trust & $\begin{array}{l}\text { Operational } \\
\text { Performance }\end{array}$ & $\begin{array}{l}\text { Supply Chain } \\
\text { Collaboration }\end{array}$ & $\begin{array}{l}\text { Information and } \\
\text { Communication } \\
\text { Technology }\end{array}$ \\
\hline OP1 & 0.831 & 0.836 & 0.828 & 0.770 \\
\hline OP2 & 0.875 & 0.920 & 0.803 & 0.807 \\
\hline OP3 & 0.786 & 0.798 & 0.787 & 0.769 \\
\hline OP4 & 0.845 & 0.928 & 0.794 & 0.810 \\
\hline OP5 & 0.755 & 0.870 & 0.779 & 0.854 \\
\hline $\mathrm{T} 1$ & 0.870 & 0.753 & 0.768 & 0.724 \\
\hline $\mathrm{T} 2$ & 0.871 & 0.810 & 0.780 & 0.759 \\
\hline T3 & 0.864 & 0.850 & 0.764 & 0.772 \\
\hline $\mathrm{T} 4$ & 0,794 & 0.778 & 0.699 & 0.706 \\
\hline T5 & 0.913 & 0.830 & 0.759 & 0.783 \\
\hline SCC1 & 0.693 & 0.702 & 0.756 & 0.650 \\
\hline SCC2 & 0.734 & 0.774 & 0.787 & 0.832 \\
\hline $\mathrm{SCC} 3$ & 0.707 & 0.764 & 0.853 & 0.740 \\
\hline SCC4 & 0.608 & 0.668 & 0.769 & 0.573 \\
\hline SCC5 & 0.624 & 0.657 & 0.815 & 0.712 \\
\hline SCC6 & 0.661 & 0.662 & 0.790 & 0.677 \\
\hline ICT1 & 0.752 & 0.836 & 0.786 & 0.916 \\
\hline ICT2 & 0.731 & 0.742 & 0.773 & 0.828 \\
\hline ICT3 & 0.793 & 0.833 & 0.774 & 0.882 \\
\hline ICT4 & 0.779 & 0.805 & 0.751 & 0.812 \\
\hline ICT5 & 0.653 & 0.712 & 0.703 & 0.837 \\
\hline
\end{tabular}

Source: Primary Data Processed, 2019

\section{Unidimensionality}

To ensure that the measurement is problem-free, the final step in the outer model evaluation is testing the model unidimensionality. Unidimensionality test is done using composite reliability and Cronbach's alpha with the cut-off value of 0.7 .

Table 2. Composite Reliability and Cronbach's Alpha

\begin{tabular}{lrr}
\hline & Cronbach's Alpha & \multicolumn{1}{c}{$\begin{array}{c}\text { composite } \\
\text { Reliability }\end{array}$} \\
\hline Trust & 0.914 & 0.936 \\
Operational Performance & 0.920 & 0.940 \\
Supply Chain Collaboration & 0.884 & 0.912 \\
Information and Communication Technology & 0.908 & 0.932 \\
\hline
\end{tabular}

Source: Primary Data Processed, 2019 
The table above shows that all constructs produced a composite reliability and Cronbach Alpha of higher than 0.7. Therefore, no unidimensionality or reliability problem was found in the model tested. The second part of the evaluation is to assess the results of the structural model (inner model) which can be done using three methods: $\mathrm{R}^{2}, \mathrm{Q}^{2}$, and Gof (Goodness of fit).

Table $3 \mathrm{R}$ square

\begin{tabular}{lr}
\hline & R Square \\
\hline Operational Performance & 0.940 \\
Supply Chain Collaboration & 0.829 \\
\hline Source: Primary Data Processed, 2019
\end{tabular}

Determining whether a hypothesis is accepted or rejected can be done by looking at the significance value between the constructs, the t-statistics, and the p-values. In this way, the estimated standard error of measurement is no longer calculated using statistical assumptions, but rather based on empirical observations. In the bootstrapping method in this study, the hypothesis is accepted if the significance value of t-values is $>1.96$ and or p-value is $<0.05$. If so, Ha is accepted and Ho is rejected.

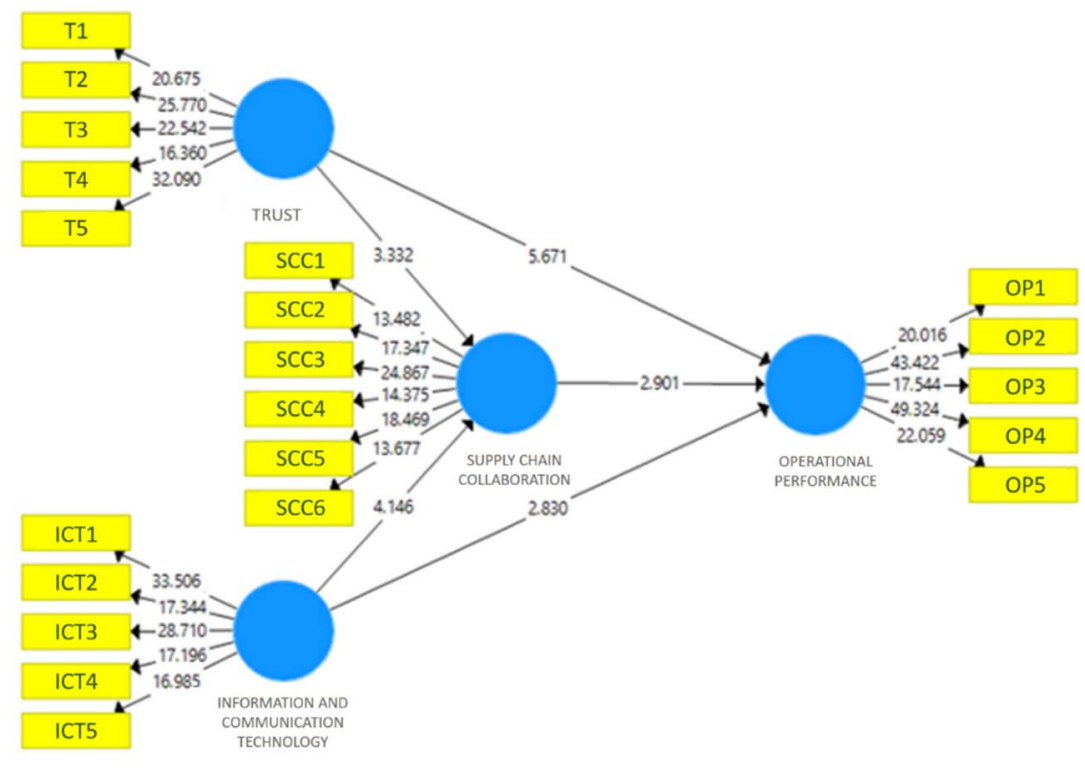

Figure 3. Structural Model Testing

In Table 4 , it can be seen that trust influences $(\mathrm{O}=0.484)$ operational performance. The value of tstatistic on the relationship of these two constructs was 5.671, and the p-value was 0.000 . Therefore, the first hypothesis stating that trust positively and significantly influences operational performance is proven. This study is in line with the research conducted by Kwon and Taewon (2004), which found that the successful performance of the company (operational performance) in the supply chain is the result of a strong trust and commitment among partners in the supply chain.

Based on Table 4, it can be seen that ICT influences $(O=0.292)$ operational performance. T-statistic in this construct relationships was 2.830 and p-value of 0.005 . Therefore, the second hypothesis stating that ICT positively and significantly influences operational performance is proven. This finding is consistent with the result of Tripathy (2016), which states that ICT is key for operational effectiveness, which increases the competitive advantage of supply chain management, which further accelerate customer relationships and supplier relationships. 
Table 4. Path Coefficients

\begin{tabular}{lccccc}
\hline & $\begin{array}{c}\text { Original } \\
\text { Sample } \\
(\mathrm{O})\end{array}$ & $\begin{array}{c}\text { Sample } \\
\text { Mean } \\
(\mathrm{M})\end{array}$ & $\begin{array}{c}\text { Standard } \\
\text { Deviation } \\
(\text { STDEV })\end{array}$ & $\begin{array}{c}\text { T Statistics } \\
(\text { ( O/STDEV I) }\end{array}$ & $\begin{array}{c}\mathrm{P} \\
\text { Values }\end{array}$ \\
\hline $\begin{array}{l}\text { Trust } \rightarrow \text { Operational Performance } \\
\text { Trust } \rightarrow \text { Supply Chain Collaboration }\end{array}$ & 0.484 & 0.481 & 0,085 & 5.671 & 0.000 \\
$\begin{array}{l}\text { Supply Chain Collaboration } \rightarrow \text { Operational } \\
\text { Performance }\end{array}$ & 0.425 & 0.431 & 0.128 & 3.332 & 0.001 \\
$\begin{array}{l}\text { Information and Communication } \\
\text { Technology } \rightarrow \text { Operational Performance }\end{array}$ & 0.292 & 0.234 & 0.081 & 2.901 & 0.004 \\
$\begin{array}{l}\text { Information and Communication } \\
\text { Technology } \rightarrow \text { Supply Chain Collaboration }\end{array}$ & 0,517 & 0.514 & 0,125 & 4.146 & 0.000 \\
$\begin{array}{l}\text { Trust } \rightarrow \text { Supply Chain Collaboration } \rightarrow \\
\text { Operational Performance }\end{array}$ & 0,100 & 0.098 & 0,040 & 2.519 & 0.012 \\
$\begin{array}{l}\text { Information and Communication } \\
\begin{array}{l}\text { Technology } \rightarrow \text { Supply Chain Collaboration } \\
\rightarrow \text { Operational Performance }\end{array}\end{array}$ & 0.121 & 0.123 & 0.058 & 2.095 & 0.037 \\
\hline
\end{tabular}

Source: Primary Data Processed, 2019

Trusts also influences $(O=0.425)$ supply chain collaboration. T-statistic value in this relationship was 3.332 and p-value was 0.001 . Therefore, the second hypothesis stating that ICT positively and significantly influences operational performance is proven. This study is in line with the research conducted by Salam (2017), which found that collaboration of two or more companies can be successful if it is built on trust (Salam, 2017). This finding is reinforced by the research by Chopra and Meindl (2007), which states that one of the most important factors that each company in the supply chain needs to have is a network of trust among organizations. Trust is the bond that holds a collaborative relationship (Spekman and Carraway 2006).

ICT has an influence $(\mathrm{O}=0.517)$ on supply chain collaboration. The value of t-statistics in this relationship was 4.146 , and the p-value was 0.000 . Therefore, the fourth hypothesis stating that ICT positively and significantly influences supply chain collaboration is proven. This result is in line with the research conducted by Salam (2017), which asserts that in order to achieve collaborative supply chain relationship, electronic mechanism should exist so that information can be easily exchanged between partners. One such mechanism is a technology for sharing information and communication. Information and communication technology support allows the management to make business decisions more quickly and accurately (Munizu, 2015). Levi et al. (2004) defines information technology (IT) as tools, either hardware or software, used to determine the existence of information and analyze such information to make the best decisions for the supply chain.

Supply chain collaboration shows an effect $(\mathrm{O}=0.235)$ on operational performance. $\mathrm{T}$ statistic value in this relationship was 2.901 and the p-value was 0.004 . Therefore, the fifth hypothesis stating that supply chain collaboration positively and significantly influences operational performance is proven. Collaboration allows faster development of new products, better product quality, lower product cost and supply chains, shorter cycle times and improved customer service (Cachon and Fisher, 2000; Frohlich, 2002; Ketchen et al., 2007; Rinehart et al., 2008).

To measure how far the supply chain collaboration can mediate the effect of ICT on trust and operational performance can be seen in the Table on specific indirect effects on the results of PLS bootstrapping. Table 4 shows that supply chain collaboration can mediate the effect of confidence in the operational performance significantly with a p-value of 0.012 and t-statistic value of $2.519>1.96$ ( $\mathrm{t}>\mathrm{t}$ table). Therefore, the sixth (a) hypothesis stating that supply chain 
collaboration mediates the effect of trust on operational performance is proven. This finding is in line with some studies which found that joint efforts enable partners to align their operations and processes, which improve relationships by building trust.

Collaborative supply chain can also mediate the effect of ICT on operational performance significantly with a p-value of 0.037 and t-statistic value of $2.095>1.96(t>t$ table). Therefore, the sixth (b) hypothesis stating that supply chain collaboration mediates the effect of ICT on operational performance is proven. Myhr and Spekman (2005) found that the collaborative partnership can be achieved through trust or electronically mediated exchange (e.g. information and communication technologies).

\section{Conclusions}

The results of this study provide empirical evidence that the enabling factors of supply chain collaboration have been proven significant to directly influence operational performance and supply chain collaboration. Also, the role of supply chain collaboration proved capable of mediating the indirect effect of trust and ICT variables on operational performance through supply chain collaboration. These results suggest that screen printing SMEs as one of the creative industries are able to develop cooperation with their partners due to their ability maintain trust and develop effective information system to share data and information.

Higher confidence will strengthen the cooperation among SMEs with long-term partners and will improve their performance. To maintain long-term relationships, informal contracts must be written, so that both sides will have a strong commitment to cooperation based on mutual trust.

ICT is believed to play a key role in promoting cooperation sustainability as it can facilitate planning, forecasting, and fulfillment of customers' demand collaboratively. Screen printing industry is one industry with uncertain change of demands, so screen printing SMEs are required to always perform demand forecasting, market trend analysis, and data improvement in order to create a cooperation synergy.

\section{References}

Anderson, James C. and James A. Narus, 1990, A models of distributor firm and manufacturing firm working relationships, Journal of Marketing 54 (1): 42-58. https://doi.org/10.2307/1252172,

Barratt, Mark and Alexander Oliveira, 2001, Exploring the experiences of collaborative planning Initiatives. International Journal of Physical Distribution \& Logistics Management, Vol. 31 No. 4, pp. 266-289.http://dx.doi.org/10.1108/09600030110394932

Bowersox, Donald J., 1990, The strategic benefits of logistics alliances. Harvard Business Review, Vol. 68 No. 4, pp. 36-43.

Cachon, Gerard P. and Marshall Fisher, 2000, Supply chain inventory management and value of shared information, Management Science, Vol. 46 No. 8, pp. 1032-1048.

Chopra, Sunil and Peter Meindl, 2007, Supply Chain Management: Strategy, Planning, and Operation. International Journal of Quality \& Reliability Management, Vol. 20 No. 3, pp. 398-400.

Clemons, Eric K and Michael C. Row, 1992, Information technology and industrial cooperation: The changing economics of coordination and ownership. Journal of Management Information Systems, Vol. 9 No. 2, pp. 9-28.

Doney, Patricia M. and Joseph P. Cannon, 1997, An examination of the nature of trust in buyer suppliers relationships, Journal of Marketing, Vol. 61 No. 2, pp. 35-51. 
Frankel, Robert, Thomas J. Goldsby and Judith M. Whipple, 2002, the Grocery industry collaboration in the wake of the ECR. International Journal of Logistics Management, Vol. 13 No. 1, pp. 5772.

Ganesan, Shankar, 1994, Determinants of long-term orientation in buyer-seller relationships, Journal of Marketing, Vol. 58 No. 2, No. 1-19.

Ghozali, Priest, 2011, Applications Multivariate Analysis with SPSS Program. Semarang: Diponegoro University

Hamidin, Dini, Akhamad Greece, and Azizah zakiah, 2013, Creation Collaboration On Supply Chain Management SME. FEB Unsoed Journal and Proceedings, Vol. 3 No. 1

Heizer, Jay, and Berry Render, 2015, Operations Management: Sustainability and Supply Chain Management, Translation by Hirson Kurnia, Ratna Saraswati, and David Wijaya, Jakarta: Four Salemba.

Hussein, Ananda Sabil, 2015, Penelitian Bisnis dan Manajemen menggunakan Partial Least Square (PLS) dengan SmartPLS 3.0, Modul Ajar Jurusan Manajemen Fakultas Ekonomi dan Bisnis Universitas Brawijaya

Kwon, Ik-Whan G. and Taewon Suh 2004, Factors affecting the level of trust and commitment in supply chain relationships, Journal of Supply Chain Management 40 (1): 4-14. https: // doi. org / 10.1111 / j.1745-493X.2004.tb00165.x

Levi, David Simchi, Philip Kaminsky, and Edith Simchi-Levi, 2004, Managing the Supply Chain: The Definitive Guide for the Business Professional. USA: McGraw-Hill Inc.

Mayer, Roger C., James H. Davis and F. David Schoorman, 1995, An integrative models of organizational trust. Academy of Management Review, Vol. 29 No. 3, pp. 709-34.

Monczka, Robert M., Kenneth J. Petersen, Robert B. Handfield, and Gary L. Ragatz, 1998, Success factors in strategic supplier alliances: The buying company perspective.Decision Sciences, Vol. 29 No. 3, pp. 553-577.

Moorman, Christine, Rohit Deshpande and Gerald Zaltman, 1993, Factors affecting trust in market research relationships, Journal of Marketing, Vol. 57, No. 1 (Jan., 1993), pp. 81-101

Morgan, Robert M. and Shelby D. Hunt, 1994, The commitment of trust theory of relationship marketing, Journal of Marketing, Vol. 58 (July), pp. 20-38.

Munizu, Musran, 2017, Effect of Trust, Commitment, Information Technology and Supply Chain Performance Against (Case Study Ikm Passion Fruit Processing In Makassar). Journal of Management and Agribusiness, Vol. 14 No. 1.

Narus, James A. and James C. Anderson, 1996, Rethinking distribution: Adaptive channels. Harvard Business Review, Vol. 74 No. 4, pp. 112-20.

Panahifar, Farhad, PJ Byrne, Mohammad Asif Salam, Cathal Heavey, 2018, Supply chain collaboration and firm performance: the critical role of information sharing and trust, Journal of Enterprise Information Management, Emerald Group Publishing.https://doi.org/10.1108/JEIM-08-2017-0114

Papakiriakopoulos, Dimitris and Katerina Pramatari 2010, Collaborative performane mesurement in the supply chain, Industrial Management \& Data Systems, Vol. 110 No. 9, 1297-1318.

Pienaar. 2009. Business Logistics Management 5th Edition. South America: Oxford University Press. 
Pramatari, Katerina, 2007, Collaborative supply chain practices and evolving technological approaches. Supply Chain Management: An International Journal, Vol. 12 No. 3, pp. 210220.

Prasetyo, Adi, 2013, the Information Sharing Analysis and Quality Information On Supply Chain Management Case Study at Boutique And Gallery Batik Yogyakarta (Guided By Kusmantini point, Se., M.Si Dan Tri Wahyuningsih, Se., M.Si). http://eprints.upnyk.ac.id/9469/2/ABSTRAKSI.pdf

Pujawan, L Nyoman. And Mahendrawathi Er, 2017, Supply Chain Management Edition 3. Yogyakarta: Yogyakarta ANDI.

Russell and Taylor, 2011, Operations Management Seventh Edition, United States of America: John Wisley and Sons, Inc.

Salam, Mohammad Asif, 2017, The mediating role of supply chain collaboration on the relationship between technology, trust and operational performance: an empirical investigation, Benchmarking: An International Journal, Vol. 24 Iss 2 pp, Emerald Group Publishing,http://dx.doi.org/10.1108/BIJ-07-2015-0075

Simatupang, Togar M., Alan C. Wright, and Ramaswami Sridharan, 2002 The knowledge of coordination for supply chain integration, Business Process Management Journal, Vol. 8 No. 3, pp. 289-308.

Spekman, Robert E., and Robert Carraway, 2006 Making the transition to collaborative buyer-seller relationships: An emerging framework, Industrial Marketing Management, Vol. 35 No. 1, pp. 10-19.

Sudin, Ghofar Abdul Sharif Alam, 2004 Influence on Performance of Manufacturing Strategy. Maranantha Management Journal, Volume 3, May 2004, page 118.

Sugiyono, 2012, Quantitative Research Methods, Qualitative and R \& D, Bandung: Alfabeta.

Tripathy, Sushanta, Satyabrata Aich, Anurup Chakraborty and M. Lee Gyu, 2016, Information technology is an enabling factor affecting supply chain performance in Indian SMEs: A structural equation modeling approach, Journal of Modeling in Management, Vol. 11 Issue 1, pp.269-287. Emerald Group Publishing.https://doi.org/10.1108/JM2-01-2014-0004

Turban E, Linda V, 2010, Information Technology for Management: Transforming Organizations in the Digital Economy, 7th Edition. USA: Wiley Inc.

Whipple, Judith M. and Robert Frankel, 2000 Strategic alliance success factors, Journal of Supply Chain Management, Vol. 36 No. 3, pp. 21-28

Wong Chee Yew, Sakun Boon-itt, Christina WY Wong, 2011, The contingency effects of environmental uncertainty on the relationship between supply chain integration and operational performance, Journal of Operations Management, OPEMAN-742; No. of Pages 12.

Yaqoub, Amak M., 2012, Effect of Trust On The Relationship Between Mediation Collaborative Supply Chain and Operational Performance, Journal of Management and Entrepreneurship, 14 (2), 138-146. https://doi.org/10.9744/jmk.14.2.138-146 